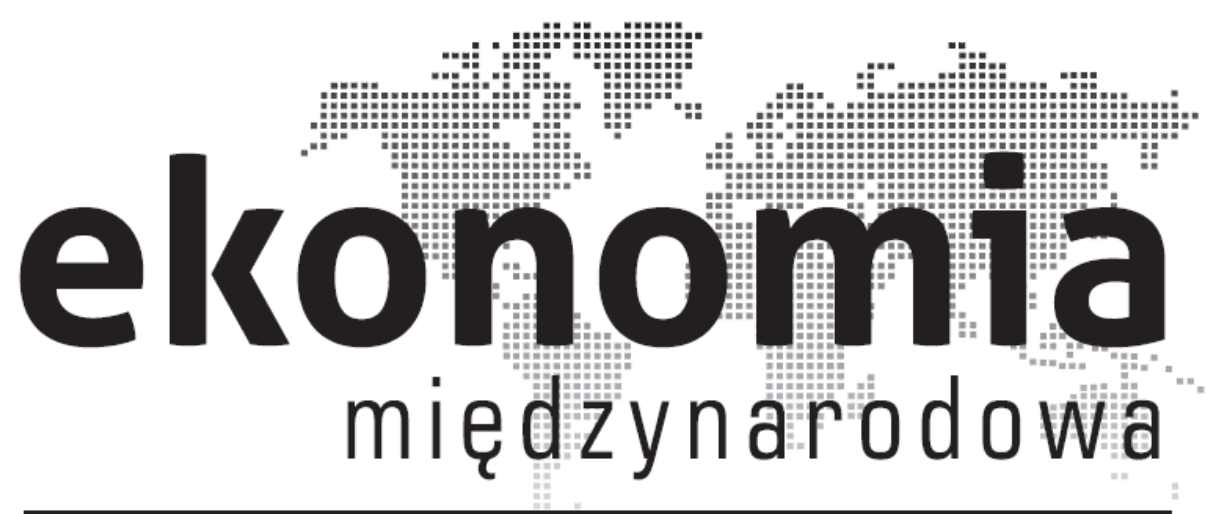

Ekonomia Międzynarodowa

$\mathrm{Nr} 13$ (2016)

Wydawca: Uniwersytet Łódzki

(Publisher: University of Lodz)

www.ekonomia-m.pl

ISSN: 2082-4440 - wydanie papierowe (paper edition)

ISSN: 2300-6005 - wydanie elektroniczne (electronic edition)

Wersja elektroniczna czasopisma jest wersją referencyjną

(Electronic edition is the reference version of the journal)
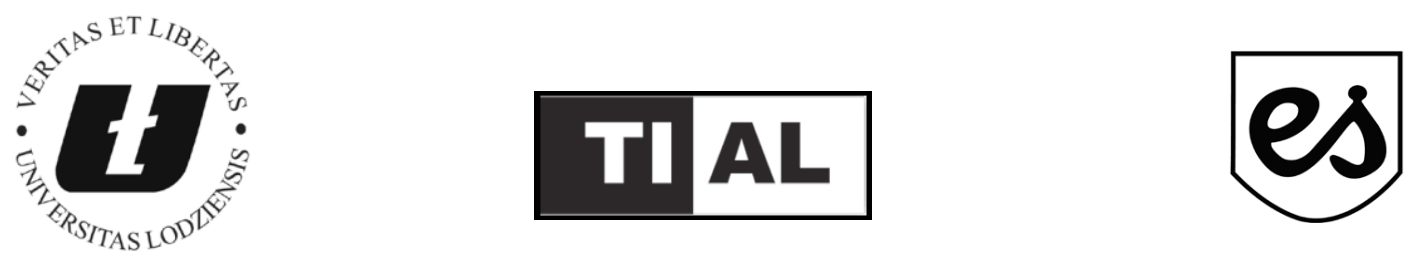


\section{Przemysł meblarski w Polsce i jego międzynarodowa pozycja konkurencyjna}

Marta Ulbrych ${ }^{*}$

\section{Wstęp}

Celem rozważań niniejszego opracowania jest konceptualizacja pojęcia międzynarodowej konkurencyjności branży, a następnie określenie metod jej pomiaru. Kategoria konkurencyjności jest wieloznaczna i relatywna, dlatego - zdając sobie sprawę ze złożoności problemu - skoncentrowano się na tradycyjnym rozumieniu pojęcia, jako zdolności do sprostania konkurencji międzynarodowej. Pomiar międzynarodowej pozycji konkurencyjnej branży oparto na wskaźnikach wynikowych. Do kwantyfikacji pozycji konkurencyjnej Polski w produkcji mebli wykorzystano mierniki określające udział w rynku, produktywność i efektywność wytwarzania. W opracowaniu wykorzystano metodę opisową popartą dynamiczną analizą danych statystycznych GUS i Eurostatu oraz raportu Centre for Industrial Studies, The EU Furniture Market Situation and a Possible Furniture Products Initiative. Final Report.

\section{Międzynarodowa pozycja konkurencyjna branży}

Mimo że pojęcie konkurencyjności należy do podstawowych terminów współczesnej ekonomii, dotychczas nie została wypracowana jedna, ścisła i powszechnie akceptowalna definicja. Dyskusja o terminie „konkurencyjność” ma długą historię, a jej wielowątkowość i wielokierunkowość nie pozwalają zaprezentować wszystkich definicji. Ponadto w literaturze można znaleźć obszerny przegląd i systematykę w tym zakresie (Bieńkowski i in. 2008), dlatego w przypadku niniejszego opracowania przeprowadzono jedynie syntetyczną analizę najważniejszych wątków.

\footnotetext{
* Marta Ulbrych - dr nauk ekonomicznych, Uniwersytet Ekonomiczny w Krakowie, Wydział Ekonomii i Stosunków Międzynarodowych, Katedra Międzynarodowych Stosunków Gospodarczych.
} 
Niejednorodny sposób definiowania konkurencyjności pozwala na pojmowanie tej kategorii zgodnie ze specjalizacją badacza analizującego to zjawisko. Zasadniczo można wyodrębnić cztery nurty badań nad konkurencyjnością, które czerpią z dorobku teorii wzrostu gospodarczego, handlu międzynarodowego, zniekształceń oraz konkurencji, w tym mikroekonomii. W pierwszym ujęciu podmiot analizy jest kraj, a jego konkurencyjność ocenia się na poziomie makroekonomicznym za pomocą mierników wzrostu i rozwoju gospodarczego. W przypadku drugiego nurtu badań ocenia się konkurencyjność przez pryzmat wyników handlu zagranicznego, przyjmując że różnice w wydajności pracy między produktami wytwarzanymi w różnych krajach wyznaczają strukturę towarową strumieni handlowych ${ }^{1}$. Trzecie podejście metodologiczne nawiązuje do teorii zniekształceń i wykorzystuje analizę cenowo-kosztową. Ostatni, czwarty, nurt badań nad konkurencyjnością nawiązuje do procesów konkurencji między podmiotami gospodarczymi (Wziątek-Kubiak 2003, s. 14-21).

Różnicowanie się nurtów badań nad konkurencyjnością znajduje odzwierciedlenie także w rozważaniach nad sześcioma głównymi poziomami hierarchii systemów gospodarczych: mikro-mikro, mikro, mezo, makro, regionalny i globalny (Gorynia 2009, s. 51-53). Poziom mikro-mikro bada ekonomiczne aspekty zachowań człowieka i dotyczy indywidualnych konsumentów i przedsiębiorców oraz pojedynczych pracowników. Poziom mikro dotyczy przedsiębiorstw (niejednoosobowych) i gospodarstwadomowych. Poziom mezo obejmuje branże, sektory czy gałęzie gospodarki narodowej, ale także wyodrębnione terytorialnie obszary kraju. Poziom makro opisuje gospodarki narodowe poszczególnych krajów, a regionalny dotyczy grupy państw. Wreszcie poziom globalny ma zastosowanie w odniesieniu do gospodarki światowej. Należy także zwrócić uwagę na problem współzależności między opisanymi wzajemnie przenikającymi się aspektami konkurencyjności.

W literaturze można znaleźć różnorakie podejścia definicyjne do badanego zjawiska. Zasadniczo można przyjąć, że konkurencyjność jest tożsama ze zdolnością do konkurowania oraz faktycznym poziomem wykorzystania tej zdolności, która wiążę się z pozycją konkurencyjną (Sztando 1999, s. 211). Tym samym można wyróżnić dwa pojęcia, czyli międzynarodową zdolność konkurencyjną i międzynarodową pozycję konkurencyjną. Międzynarodowa zdolność konkurencyjna lub międzynarodowa przewaga konkurencyjna (tzw. konkurencyjność typu czynnikowego) określa właśnie możliwość i skłonność do osiągania korzyści z uczestnictwa w międzynarodowym podziale pracy. Pozycja konkurencyjna jest pojęciem węższym, wynikowym, stąd jest określana także jako konkurencyj-

\footnotetext{
${ }^{1}$ Należy jednak zwrócić uwagę na potrzebę odróżnienia kategorii konkurencyjności od pojęcia korzyści komparatywnych. Korzyść komparatywna jest rozumiana jako zdolność gospodarki do efektywniejszego niż w innych gospodarkach wytwarzania dobra, wyraża się w kierunkach specjalizacji eksportowej i importowej kraju. Decydujące znaczenie mają zatem relatywne wyposażenie w czynniki produkcji, struktura kosztów produkcji, struktura popytu, korzyści skali itd., podczas gdy przewaga konkurencyjna wynika z relatywnej siły określonej gospodarki w stosunku do zagranicznych konkurentów (Person, Salenbier 1983 [za:] Wysokińska 2002, s. 127).
} 
ność typu wynikowego. Precyzuje ona rezultat konkurowania, czyli np. udział w handlu międzynarodowym (Misala 2005, s. 287-288). W odróżnieniu od pozycji zdolność konkurencyjna gospodarki stanowi ocenę jej potencjału i określa prawdopodobny kierunek jej rozwoju w kontekście międzynarodowym. W ujęciu realnym przewaga konkurencyjna kraju ma źródło w redukcji kosztów, ale także w dywersyfikacji produkcji, poprawie jakości oraz indywidualizacji, a także innowacyjności podaży (Bossak 2013, s. 175-176). Niemniej obie wyróżnione kategorie są współzależne, ponieważ osiągnięta pozycja konkurencyjna jest równocześnie wynikiem i determinantą zdolności konkurencyjnej.

Należy także podkreślić, że międzynarodowa konkurencyjność gospodarki danego kraju jest rezultatem kształtowania się konkurencyjności podmiotów działających na tym rynku. Istotny wpływ na badania nad konkurencyjnością wywarły prace M.E. Portera, któremu zawdzięczamy rozróżnienie między przewagą konkurencyjną kraju a przewagą konkurencyjną przedsiębiorstwa (Porter 1990, s. 73-91). Według niego, wyjaśniając konkurencyjność na szczeblu ogólnonarodowym, należy badać jej efektywność, a można tego dokonać, koncentrując się na konkretnych sektorach gospodarki i ich produktywności.

Obecnie nie ma wątpliwości, że budowanie przewagi konkurencyjnej jest udziałem przede wszystkim przedsiębiorstw, jednak warto pamiętać, że ich powodzenie często jest uzależnione od sprawnie działającego otoczenia gospodarczego. P. Krugman sprzeciwia się stosowaniu pojęcia konkurencyjności na poziomie makroekonomicznym (Krugman 1994). Jednocześnie zwraca uwagę na to, że obsesyjne dążenie do poprawy konkurencyjności może być realnym zagrożeniem i prowadzić do marnotrawienia publicznych pieniędzy. Zasadne zatem wydaje się pytanie o prerogatywy polityki gospodarczej i zakres jej aktywnego oddziaływania na podmioty gospodarcze $\mathrm{w}$ celu poprawienia ich konkurencyjności i poziomu umiędzynarodowienia. Można się zgodzić, że strategicznymi zaleceniami dla polityki gospodarczej pozostają: tworzenie warunków sprzyjających prowadzeniu działalności gospodarczej oraz pobudzanie przedsiębiorczości i promowanie tzw. „kultury sieciowania", czyli współpracy między podmiotami mogącymi oddziaływać na innowacyjność przedsiębiorstw (M. Gorynia, B. Jankowska 2008, s. 186-190). Warto zwrócić uwagę na potrzebę sporządzania analiz branżowych, które mogą być przydatne organom władzy państwa. Te z kolei - ustalając odpowiednie priorytety polityki gospodarczej, w tym przemysłowej - mogą wpływać na konkurencyjność gospodarki narodowej.

W tym kontekście należy określić istotę międzynarodowej konkurencyjności na poziomie mezoekonomicznym. M. E. Porter właśnie w tym przypadku upatruje relatywnie największej liczby sukcesów w badaniach nad konkurencyjnością. Mezokonkurencyjność można definiować jako , zdolność do projektowania i sprzedawania towarów danej branży, gałęzi lub działu, których ceny, jakość i inne walory są bardziej atrakcyjne od odpowiednich cech towarów oferowanych przez konkurentów" (Flejterski 1984, s. 23 [za:] Daszkiewicz 2008, s. 14). Doprecyzowania wyma- 
gają także kryteria delimitacji branży w teorii i w praktyce gospodarczej dla celów statystycznych. Pojęcie branży wiąże się z ekonomią branży, w tradycji anglosaskiej mówi się o industrial economics lub industrial organisation. Przedmiotem dyskusji jest metodologia grupowania przedsiębiorstw. O ile nie ma sporu co do podziału pionowego, w którym branża jest umieszczana między gospodarką narodową a przedsiębiorstwem, o tyle wymiar poziomy definiowany jest na różne sposoby; można zasadniczo wyodrębnić podejścia uwzględniające kryteria podażowe i popytowe. Tym samym typologia ta może się odnosić do podobieństwa: produktów, technologii produkcji lub potrzeb zaspokajanych przez produkty/usługi przedsiębiorstwa (Jankowska 2009, s. 105-107). Koncepcje te nie oferują jednak jednoznacznych narzędzi grupowania przedsiębiorstw na potrzeby analiz branżowych.

Obok ujęć proponowanych w literaturze należy uwzględnić zdefiniowanie branży w zestawieniach statystycznych. W Polsce obowiązuje Statystyczna Klasyfikacja Działalności Gospodarczej Unii Europejskiej (NACE) i opracowana na jej podstawie Polska Klasyfikacja Działalności (PKD). Grupuje ona podmioty gospodarcze według kryterium przedmiotowego i umownie przyjętego podziału. Produkcja mebli stanowi element przetwórstwa przemysłowego (sekcja C) i jest umiejscowiona $\mathrm{w}$ dziale 31.0. Podklasa ta obejmuje produkcję mebli dowolnego typu z dowolnego materiału, z wyłączeniem mebli z kamienia, betonu i ceramiki (GUS 2007).

Wielości podejść definicyjnych do pojęcia konkurencyjności międzynarodowej oraz brak zgodnego stanowiska co do jej istoty nie pozwalają jednoznacznie ustalić, jaką miarą należałoby się posługiwać w celu oszacowania poziomu konkurencyjności danego podmiotu. W systematyzacji miar konkurencyjności najczęściej stosuje się podział na miary czynnikowe i wynikowe ${ }^{2}$. Pierwsza grupa określa zdolność konkurencyjną i obejmuje ilościowe oraz jakościowe wskaźniki służące do oceny stopnia wykorzystania zasobów pracy i kapitału ludzkiego, poziomu stosowanych technologii oraz miary dotyczące regulacji i instytucji z uwzględnieniem ich wpływu na wykorzystanie i alokację zasobów (Radło 2008). Druga grupa ocenia pozycję konkurencyjną, dotyczy osiągniętego udziału w handlu światowym w wymiarze jakościowym i ilościowym oraz bada wskaźniki wydajności. Podejście to koncentruje się zatem na wynikach gospodarczych, a nie na przyczynach ich osiągnięcia.

\section{Tendencje w rozwoju branży w Polsce}

Przemysł meblarski należy do dynamicznie rozwijających się branż polskiego przemysłu przetwórczego. Produkcja mebli w Polsce stanowiła w 2013 r. 2,48\%

\footnotetext{
${ }^{2}$ Literatura dostarcza mierników syntetycznych służących do pomiaru międzynarodowej pozycji konkurencyjnej. Do najpopularniejszych należą: wskaźnik ujawnionych przewag konkurencyjnych RCA, wskaźniki pokrycia określające relację eksportu do importu (m.in. indeks Liesnera, Woltera), wskaźniki oparte na eksporcie netto (np. indeks Dongesa-Riedla, rozwinięty przez UNIDO: United Nations Industrial Development Organisation, The Industrial Competitiveness of Nations. Looking back, forging ahead, Vienn 2013).
} 
produkcji globalnej przemysłu i 2,97\% przetwórstwa przemysłowego w gospodarce narodowej. Polski rynek mebli rozwija się stabilnie. Udział tego sektora w generowaniu wartości dodanej brutto przemysłu w 2013 r. wyniósł $2,8 \% \mathrm{w}$ porównaniu z 2005 r., kiedy odpowiadał za 2,9\%. W 2013 r. w branży zajmującej się produkcją mebli zatrudnienie znalazło 157,3 tys. pracowników, co stanowiło $6,5 \%$ ogółu zatrudnionych w przetwórstwie przemysłowym (GUS 2014).

Wykres 1. Dynamika wartości dodanej brutto przemysłu w latach 2006-2013

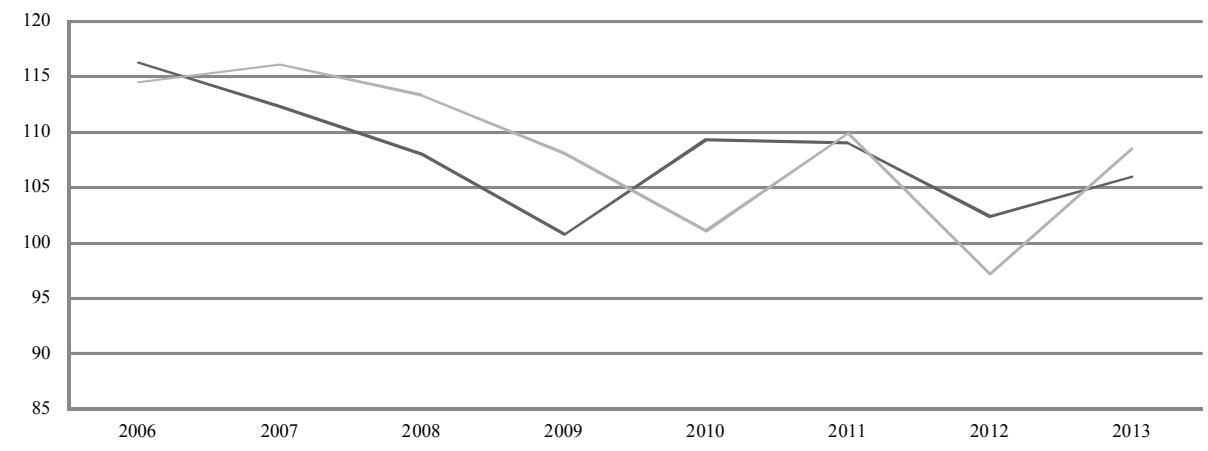

Źródło: opracowanie własne na podstawie danych GUS.

Od 2007 r. do 2009 r. dynamika wartości dodanej brutto produkcji mebli przewyższała dynamikę przetwórstwa przemysłowego (wykres 1). W latach 2010-2012 tendencja ta się zmieniła. Było to spowodowane relatywnie większym spadkiem popytu na meble jako dobro drugiej potrzeby w czasie globalnego kryzysu finansowego. Niemniej w analizowanym okresie nastąpił wzrost sektora, a wartość dodana brutto produkcji mebli w 2013 r. była wyższa o 91,5\% w porównaniu z 2005 r., podczas gdy w zakresie przetwórstwa przemysłowego zmiana ta wyniosła $84,6 \%$.

Wartość produkcji sprzedanej mebli w 2013 r. wyniosła 31,6 mld zł i była wyższa o 45,8\% w porównaniu z 2005 r., w którym była równa 21,6 mld zł.

Tabela 1. Regionalny udział produkcji mebli w przetwórstwie przemysłowym w latach 2005, 2010 i 2013

\begin{tabular}{|l|c|c|c|}
\hline \multirow{2}{*}{ Jednostka terytorialna } & \multicolumn{3}{|c|}{ Udział produkcji sprzedanej mebli w przetwórstwie przemysłowym } \\
\cline { 2 - 4 } & 2005 & 2010 & 2013 \\
\hline dolnośląskie & 6,74 & 2,36 & 2,26 \\
\hline kujawsko-pomorskie & 4,64 & 3,14 & 3,74 \\
\hline lubelskie & 10,20 & 6,48 & 4,73 \\
\hline lubuskie & 5,32 & 3,05 & 1,79 \\
\hline łódzkie & 2,42 & 2,19 & 1,78 \\
\hline małopolskie & 1,34 & 11,61 & 1,08 \\
\hline
\end{tabular}




\begin{tabular}{|l|c|c|c|}
\hline mazowieckie & 1,35 & 0,68 & 0,90 \\
\hline opolskie & 3,70 & 3,01 & 2,30 \\
\hline podkarpackie & 6,05 & 5,17 & 3,75 \\
\hline podlaskie & 3,54 & 1,53 & 1,87 \\
\hline pomorskie & 2,43 & 1,92 & 1,56 \\
\hline śląskie & 0,70 & 0,53 & 0,68 \\
\hline świętokrzyskie & 0,47 & 0,45 & 0,42 \\
\hline warmińsko-mazurskie & 15,69 & 11,52 & 11,17 \\
\hline wielkopolskie & 5,69 & 7,16 & 7,01 \\
\hline zachodniopomorskie & b.d. & b.d. & b.d. \\
\hline
\end{tabular}

Źródło: opracowanie własne na podstawie danych GUS.

Analizując regionalny udział produkcji mebli w przetwórstwie przemysłowym, można zauważyć, że największy odsetek przypada na województwa wielkopolskie i warmińsko-mazurskie, które w 2013 r. odpowiadały za ponad 34\% ogółu produkcji sprzedanej w Polsce (dane wojewódzkie GUS). Równocześnie branża ta odpowiada za istotną część produkcji sprzedanej przetwórstwa przemysłowego, zarówno w województwie warmińsko-mazurskim, jak i wielkopolskim, ale także lubelskim, podkarpackim i kujawsko-pomorskim. Należy jednak odnotować, że we wszystkich wymienionych województwach nastąpił spadek udziału produkcji mebli w przetwórstwie przemysłowym pomiędzy 2005 a 2013 r., przy czym największy w lubelskim i warmińsko-mazurskim, o 5,48 i 4,51 pkt. proc. (tabela 1). Geograficzna koncentracja produkcji mebli ma historyczne uwarunkowania. Ponadto w regionach tradycyjnie zajmujących się meblarstwem miał miejsce intensywny rozwój przedsiębiorstw branżowych w ostatnich dwóch dekadach (Grupa Doradców Biznesowych BAA 2011).

Wzrostowi produkcji mebli towarzyszył intensywny wzrost eksportu wyrobów tego sektora (wykres 2) 3 $^{3}$. Eksport mebli w 2013 r. odpowiadał za 4,4\% eksportu przetwórstwa przemysłowego, a w imporcie wskaźnik ten kształtował się na poziomie $1,3 \%$. Saldo obrotów handlu zagranicznego w tej branży charakteryzowało się dodatnimi wielkościami, ponadto w latach 2010-2013 średnioroczne tempo wzrostu eksportu przewyższyło tempo wzrostu importu. Głównymi odbiorcami polskich produktów są konsumenci z krajów członkowskich Unii Europejskiej - w 2013 r. 83,1\% wartości eksportu trafiło na obszar Jednolitego Rynku (GUS 2014). Branża

\footnotetext{
${ }^{3} \mathrm{~W} 2010$ r. udział eksportu w produkcji sprzedanej mebli wyniósł 55,5\%, w kolejnym roku wzrósł do $66,2 \%$ i od tego czasu utrzymuje się na poziomie $70 \%$. Analiza opracowań dotyczących branży meblarskiej w Polsce wskazuje na większy udział eksportu w produkcji sprzedanej - ok. 90\% (np. Market Quest 2014). Podobnie dane zaprezentowane w kolejnym punkcie niniejszego opracowania dostarczają wyższe wartości w tym zakresie. Mając świadomość tych rozbieżności, postanowiono jednak przedstawić dane zaczerpnięte z jednego źródła, czyli rocznika statystycznego przemysłu.
} 
meblarska odpowiada za jedną z największych nadwyżek handlowych wśród branż przetwórstwa przemysłowego w Polsce i odnosi sukcesy na światowym rynku.

Wykres 2. Wymiana handlowa Polski w odniesieniu do wyrobów branży meblarskiej w latach 2010-2013

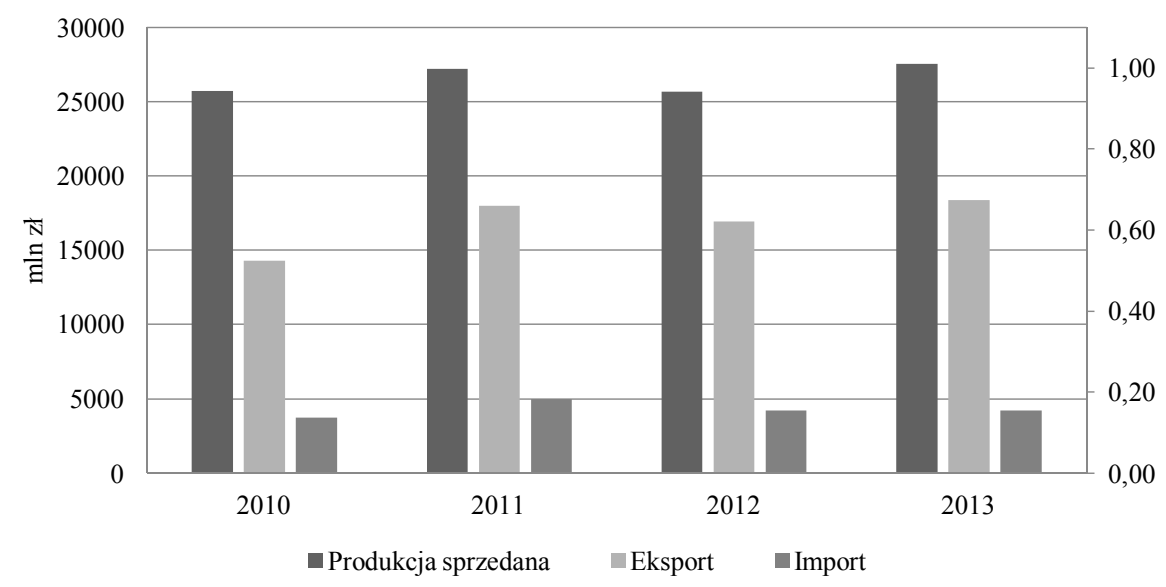

Źródło: opracowanie własne na podstawie danych GUS.

\section{Pozycja konkurencyjna polskiej branży meblarskiej}

Określenie pozycji konkurencyjnej polskiej branży meblarskiej jest procesem złożonym i trudnym do weryfikacji ze względu na wielość podejść metodologicznych w literaturze przedmiotu oraz ograniczony dostęp do danych statystycznych. Mając na uwadze te uwarunkowania, założono że konkurencyjność branży jest kategorią międzynarodową i zdefiniowano ją jako zdolność do powiększania udziałów rynkowych. Tym samym zagadnienie to jest traktowane jako swoista hybryda poziomu umiędzynarodowienia i produktywności. Ponadto pozycja konkurencyjna jest tożsama $\mathrm{z}$ wynikiem konkurowania $\mathrm{w}$ danym sektorze rozpatrywanym na tle wyników osiąganych przez konkurentów. W tym celu badaniu zostały poddane wartość produkcji oraz udział w rynku globalnym i rynku Unii Europejskiej. Rozpatrując konkurencyjność branży, należy wziąć pod uwagę dwie grupy właściwości przemysłu. Pierwszą jest zbiór cech wskazujących na produktywność przedsiębiorstw przemysłowych. Dostępność danych w tym zakresie pozwala na wartościowe ujęcie tej zmiennej dzięki ponownemu porównaniu wartości produkcji mebli. Zasadniczą wadą jest jednak pomijanie zagadnienia efektywności produkcji (Sztando 1999, s. 212-213). Niezbędne zatem wydaje się przeanalizowanie drugiej grupy właściwości określających efektywność. W tym celu posłużono się wartością dodaną brutto przypadającą na jednego zatrudnionego. 
Tabela 2. Najwięksi światowi producenci mebli w 2003 i 2012 r.

\begin{tabular}{|c|l|c|c|c|c|}
\cline { 3 - 6 } \multicolumn{2}{c|}{} & \multicolumn{4}{c|}{ Lata } \\
\cline { 2 - 6 } Lp. & \multirow{2}{*}{ Kraj } & \multicolumn{2}{c|}{2012} & \multicolumn{2}{c|}{2003} \\
\hline 1. & Chiny & 145,318 & $40 \%$ & 22,555 & $10 \%$ \\
\hline 2. & USA & 51,642 & $14 \%$ & 60,677 & $27 \%$ \\
\hline 3. & RFN & 17,738 & $5 \%$ & 15,492 & $7 \%$ \\
\hline 4. & Włochy & 15,950 & $4 \%$ & 19,338 & $9 \%$ \\
\hline 5. & Indie & 11,624 & $3 \%$ & 5,386 & $2 \%$ \\
\hline 6. & Japonia & 10,743 & $3 \%$ & 11,925 & $5 \%$ \\
\hline 7. & Polska & 8,323 & $2 \%$ & 4,393 & $2 \%$ \\
\hline 8. & Kanada & 8,262 & $2 \%$ & 8,385 & $4 \%$ \\
\hline 9. & Brazylia & 7,970 & $2 \%$ & 3,168 & $1 \%$ \\
\hline 10. & Francja & 7,929 & $2 \%$ & 7,817 & $4 \%$ \\
\hline Razem & 285,499 & $79 \%$ & 159,137 & $71 \%$ \\
\hline Pozostałe kraje & 75,363 & $21 \%$ & 63,877 & $29 \%$ \\
\hline Świat & 360,862 & $100 \%$ & 223,014 & $100 \%$ \\
\hline UE28 & 84,147 & $23 \%$ & 84,911 & $38 \%$ \\
\hline
\end{tabular}

Źródło: opracowanie własne na podstawie Centre for Industrial Studies 2014, s. 19 i 32.

W 2012 r. globalna produkcja mebli wyniosła 361 mld euro i była o 62\% wyższa niż w 2003 r. (tabela 2). Blisko 80\% produkcji w 2012 r. było skoncentrowane w dziesięciu krajach, wśród których znajduje się także Polska - na siódmym miejscu z wartością produkcji 8,3 mld euro. Odnotowano zatem awans o dwa miejsca w stosunku do 2003 r., mimo to udział w rynku międzynarodowym utrzymuje się na poziomie $2 \%$. Na uwagę zasługuje również imponujący wzrost produkcji w Chinach. W okresie 2003-2012 wartość produkcji mebli w tym kraju zwiększyła się ponad sześciokrotnie i w rezultacie Chiny, z 40-procentwym udziałem w rynku, stały się światowym liderem. Jednocześnie dostrzegalny jest wyraźny spadek udziału produkcji mebli w UE w produkcji globalnej - z 38\% w 2003 do 23\% w $2012 \mathrm{r}$.

Ze względu na silne powiązania handlowe Polski z pozostałymi krajami Unii Europejskiej skoncentrowano się na porównaniu produktywności polskiego przemysłu meblarskiego z przemysłem krajów Unii Europejskiej (tabela 3). Polska, z 10-procentowym udziałem, jest trzecim największym producentem mebli w Unii, po RFN i Włoszech. Pozycja Polski jest zatem wysoka, chociaż wciąż dwukrotnie niższa w odniesieniu do dwóch największych producentów. Analizując średnioroczną stopę wzrostu w latach 2003-2012, można jednak zauważyć, że pod względem 
wartości produkcji w Polsce badana branża rozwijała się najdynamiczniej. Należy także zwrócić uwagę na to, że znaczenie polskiego przemysłu meblarskiego w gospodarce narodowej jest stosunkowo duże, zarówno pod względem udziału w zatrudnieniu, jak i krajowej produkcji ogółem (odpowiednio 6,4\% i 2,7\%). W obu przypadkach wskaźniki odnotowane w Polsce są najwyższe w badanej grupie krajów.

Tabela 3. Najwięksi producenci mebli w Unii Europejskiej w 2012 r.

\begin{tabular}{|l|c|c|c|c|c|}
\hline Kraj & $\begin{array}{c}\text { Mln } \\
\text { EUR }\end{array}$ & Udział & $\begin{array}{c}\text { Średnioroczna } \\
\text { stopa wzrostu } \\
\text { w latach } \\
2003-2012\end{array}$ & $\begin{array}{c}\text { Udział produkcji } \\
\text { mebli w krajowej } \\
\text { produkcji ogółem }\end{array}$ & $\begin{array}{c}\text { Udział zatrudnie- } \\
\text { nia w produkcji } \\
\text { mebli w krajowej } \\
\text { produkcji ogółem }\end{array}$ \\
\hline RFN & 17,738 & $21 \%$ & $1,5 \%$ & $1,2 \%$ & $2,0 \%$ \\
\hline Włochy & 15,950 & $19 \%$ & $-2.1 \%$ & $2,2 \%$ & $3,8 \%$ \\
\hline Polska & 8,323 & $10 \%$ & $7,4 \%$ & $2,7 \%$ & $6,4 \%$ \\
\hline Francja & 7,929 & $9 \%$ & $0,2 \%$ & $0,9 \%$ & $1,9 \%$ \\
\hline Wlk. Brytania & 7,022 & $8 \%$ & $-2,5 \%$ & $1,3 \%$ & $3,5 \%$ \\
\hline Hiszpania & 4,611 & $5 \%$ & $-4,8 \%$ & $1,2 \%$ & $3,6 \%$ \\
\hline Szwecja & 3,021 & $4 \%$ & $2,4 \%$ & $1,5 \%$ & $2,5 \%$ \\
\hline Dania & 2,147 & $3 \%$ & $-2,2 \%$ & $1,9 \%$ & $3,0 \%$ \\
\hline Holandia & 2,119 & $3 \%$ & $-0,7 \%$ & $1,1 \%$ & $3,6 \%$ \\
\hline Austria & 2,115 & $3 \%$ & $-0,4 \%$ & $1,7 \%$ & $4,8 \%$ \\
\hline
\end{tabular}

Źródło: opracowanie własne na podstawie Centre for Industrial Studies 2014, s. 46.

Dominująca część produkcji mebli w Polsce jest przeznacza na eksport. W 2012 r. Polska, z wartością eksportu 6,5 mld euro, była czwartym największym dostawcą mebli na rynki zagraniczne (tabela 4).

Tabela 4. Najwięksi światowi eksporterzy mebli w latach 2003-2012, mln EUR

\begin{tabular}{|l|c|c|c|c|c|c|c|c|c|c|}
\cline { 2 - 12 } \multicolumn{1}{c|}{} & \multicolumn{10}{c|}{ Lata } \\
\hline Kraj & 2003 & 2004 & 2005 & 2006 & 2007 & 2008 & 2009 & 2010 & 2011 & 2012 \\
\hline Chiny & 6,503 & 8,270 & 10,967 & 13,800 & 16,357 & 18,481 & 18,337 & 25,165 & 27,524 & 38,387 \\
\hline RFN & 5,279 & 5,776 & 6,109 & 6,897 & 7,855 & 8,131 & 7,015 & 7,605 & 8,505 & 8,483 \\
\hline Włochy & 8,553 & 8,698 & 8,442 & 8,944 & 9,591 & 9,320 & 7,285 & 7,761 & 8,064 & 8,131 \\
\hline Polska & 3,313 & 3,867 & 4,394 & 4,898 & 5,485 & 5,767 & 4,921 & 5,701 & 6,404 & 6,513 \\
\hline USA & 2,131 & 2,198 & 2,400 & 2,620 & 2,689 & 2,869 & 2,380 & 2,919 & 3,064 & 3,816 \\
\hline
\end{tabular}

Źródło: Centre for Industrial Studies 2014, s. 30.

Ponadto, porównując dynamikę produkcji i eksportu mebli, można odnotować, że w 2012 r. wartość pierwszego wskaźnika była wyższa o 89,4\%, a drugiego o 96,6\% 
w stosunku do 2003 r. (tabela 5). Wynik ten świadczy o relatywnie dużej aktywności eksportowej polskich producentów, pozwalającej na rozszerzanie skali produkcji.

Tabela 5. Zmiany wartości produkcji i eksportu polskiej branży meblarskiej w 2012 r. $(2003=100)$

\begin{tabular}{|c|c|c|}
\hline & Produkcja & Eksport \\
\hline Polska & 189,4 & 196,6 \\
\hline
\end{tabular}

Źródło: obliczenia własne na podstawie tabel 2 i 4.

Głównym odbiorcą polskich mebli są nabywcy z krajów UE, przede wszystkim z Niemiec. W latach 2003-2012 wartość polskiego eksportu mebli na rynek UE wzrastała w tempie 7\% rocznie i w efekcie wyniosła 5,6 mld euro w 2012 r. (tabela 6).

Tabela 6. Polski eksport mebli do pozostałych krajów Unii Europejskiej w latach 2003-2012, mln EUR

\begin{tabular}{|c|c|c|c|c|c|c|c|c|c|c|}
\hline \multicolumn{10}{|c|}{ Lata } & \\
\hline 2003 & 2004 & 2005 & 2006 & 2007 & 2008 & 2009 & 2010 & 2011 & 2012 & $\begin{array}{c}\text { Średnio- } \\
\text { roczna } \\
\text { stopa } \\
\text { wzrostu }\end{array}$ \\
\hline 2,908 & 3,414 & 3,848 & 4,306 & 4,767 & 5,002 & 4,339 & 4,977 & 5,559 & 5,609 & $7,0 \%$ \\
\hline
\end{tabular}

Źródło: Centre for Industrial Studies 2014, s. 53.

Takie ukierunkowanie produkcji jest dosyć oczywiste ze względu na członkostwo Polski w Unii Europejskiej. Obserwując tendencje w zakresie światowej konsumpcji mebli w latach 2003-2012, należy jednak dostrzec malejący udział krajów członkowskich UE (tabela 7). Można zatem oczekiwać, że w dłuższej perspektywie, mimo relatywnie dobrej i ugruntowanej pozycji polskiej branży meblarskiej na obszarze Jednolitego Rynku, malejący popyt zmusi polskich producentów do poszukiwania alternatywnych rynków zbytu.

Tabela 7. Światowa konsumpcja mebli w latach 2003-2012

\begin{tabular}{|l|c|c|c|c|c|c|c|c|c|c|}
\cline { 2 - 10 } \multicolumn{1}{c|}{} & \multicolumn{7}{|c|}{ Lata } \\
\hline Grupa krajów & 2003 & 2004 & 2005 & 2006 & 2007 & 2008 & 2009 & 2010 & 2011 & 2012 \\
\hline $\begin{array}{l}\text { Kraje rozwinięte } \\
\text { (high income } \\
\text { countries) }\end{array}$ & $82 \%$ & $80 \%$ & $78 \%$ & $75 \%$ & $72 \%$ & $68 \%$ & $61 \%$ & $59 \%$ & $56 \%$ & $53 \%$ \\
\hline $\begin{array}{l}\text { Kraje średnio } \\
\text { i mniej rozwinięte- } \\
\text { (middle/low inco- } \\
\text { me countries) }\end{array}$ & $18 \%$ & $20 \%$ & $22 \%$ & $25 \%$ & $28 \%$ & $32 \%$ & $39 \%$ & $41 \%$ & $44 \%$ & $47 \%$ \\
\hline w tym EU 28 & $36 \%$ & $36 \%$ & $35 \%$ & $34 \%$ & $35 \%$ & $34 \%$ & $31 \%$ & $28 \%$ & $26 \%$ & $23 \%$ \\
\hline
\end{tabular}

Źródło: opracowanie własne na podstawie Centre for Industrial Studies, s. 26 i 33. 
W celu określenia pozycji konkurencyjnej polskiej branży meblarskiej w obszarze efektywności wytwarzania porównano wydajność pracujących (tabela 8). Wyniki w tym zakresie nie są zadawalające. Wydajność pracy w produkcji mebli w Polsce jest jedną z najniższych odnotowanych w Unii Europejskiej i zasadniczo się nie poprawia. W 2012 r. wskaźnik ten był blisko pięciokrotnie niższy w Polsce niż w Szwecji i Danii. Mniejsze wartości w analizowanym okresie obserwowano jedynie w następujących krajach: Bułgaria, Rumunia, Łotwa, Węgry, Chorwacja i Litwa. Liderami pozostają kraje skandynawskie, kraje Beneluksu oraz RFN i Austria, czyli w dużej mierze najwięksi producenci mebli w Europie.

Tabela 8. Wydajność pracy w produkcji mebli w krajach UE w latach 2010-2012 (wartość dodana brutto na zatrudnionego w tys. EUR)

\begin{tabular}{|l|c|c|c|}
\cline { 2 - 4 } \multicolumn{1}{c|}{} & \multicolumn{3}{c|}{ Lata } \\
\hline Kraj & 2010 & 2011 & 2012 \\
\hline Bułgaria & 4,7 & 4,9 & 5,6 \\
\hline Rumunia & 6,5 & 6,7 & 6,7 \\
\hline Lotwa & 7,2 & 8,1 & 8,4 \\
\hline Węgry & 10,4 & 10,9 & 10,3 \\
\hline Chorwacja & 12,2 & 11,9 & 11,0 \\
\hline Litwa & 10,8 & 11,8 & 12,3 \\
\hline Polska & 14,0 & 14,6 & 13,3 \\
\hline Portugalia & 15,6 & 14,3 & 14,2 \\
\hline Słowacja & 15,6 & 16,3 & 15,1 \\
\hline Estonia & 12,9 & 14,0 & 15,4 \\
\hline Czechy & 16,3 & 17,2 & 18,1 \\
\hline Słowenia & 17,3 & 17,9 & 19,1 \\
\hline Cypr & 25,9 & 21,7 & 19,7 \\
\hline Grecja & 29,7 & 24,0 & 20,5 \\
\hline Malta & 23,6 & 19,7 & 29,1 \\
\hline Hiszpania & 30,7 & 29,7 & 31,5 \\
\hline Wielka Brytania & 52,1 & 36,8 & 38,4 \\
\hline Włochy & 37,0 & 43,6 & 41,0 \\
\hline Irlandia & b.d. & b.d. & 41,5 \\
\hline Luksemburg & 41,1 & 42,6 & $46,9,6$ \\
\hline Finlandia & 45,2 & 45,3 & \\
\hline Francja & 46,3 & \multicolumn{2}{c|}{} \\
\hline Austria & & & \\
\hline
\end{tabular}




\begin{tabular}{|l|l|l|l|}
\hline RFN & 48,8 & 49,2 & 52,7 \\
\hline Belgia & 54,0 & 54,8 & 55,5 \\
\hline Holandia & 56,3 & 56,8 & 57,8 \\
\hline Dania & 69,9 & 58,0 & 60,3 \\
\hline Szwecja & 55,5 & 59,6 & 61,1 \\
\hline
\end{tabular}

Źródło: opracowanie własne na podstawie danych Eurostatu.

Analizowany miernik pokazuje efektywność wykorzystania pracy w procesie tworzenia wartości dodanej. Większa wydajność pracy świadczy oczywiście o wyższej pozycji konkurencyjnej danego przemysłu, ponieważ oznacza, że stosowane są w nim bardziej zaawansowane technologie produkcji, a sprawność zarządzania jest lepsza. Interesujące jest pytanie o przyczyny wskazanej relatywnej przewagi konkurencyjnej polskiej branży meblarskiej w stosunku do głównych konkurentów w Unii Europejskiej.

Analiza danych zagregowanych na wykresie 3, który przedstawia koszt zatrudnienia pracownika jako procent wartości produkcji mebli w latach 2010-2012, pozwala wskazać podstawową zaletę polskiej branży meblarskiej. Koszty pracy w Polsce należą do jednych z najniższych w Unii Europejskiej; niższe wartości odnotowano jedynie w Bułgarii i na Litwie.

Wykres 3. Koszt zatrudnienia pracownika w latach 2010-2012 (\% wartości produkcji mebli)

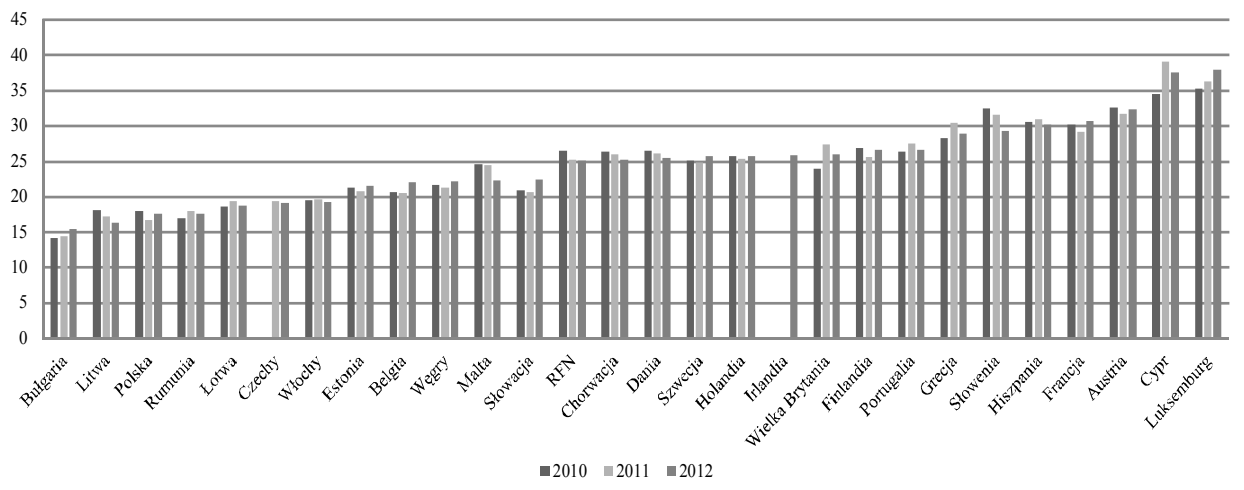

* Brak danych dla Irlandii w latach 2010 i 2011.

Źródło: opracowanie własne na podstawie danych Eurostatu.

Identyfikacja determinant międzynarodowej konkurencyjności branży wymaga oczywiście dalszych badań. Interesująca pozostaje też kwestia analizy głębszego wymiaru konkurencyjności badanej branży, w tym intensywności i jakości relacji z otoczeniem zewnętrznym, ze szczególnym uwzględnieniem roli administracji publicznej. 


\section{Podsumowanie}

Przeprowadzona analiza pozwala wnioskować, że Polska branża meblarska ma istotne znaczenie, jeśli chodzi o pozycję konkurencyjną gospodarki narodowej. Polska jest jednym z najszybciej rozwijających się pod względem poziomu produkcji rynków meblarskich w Unii Europejskiej. Sektor meblarski w Polsce jest silnie skoncentrowany $\mathrm{w}$ województwach wielkopolskim i warmińsko-mazurskim, z których pochodzi ponad 1/3 krajowej produkcji mebli. Odnosząc wartość produkcji mebli w Polsce oraz udział w rynku globalnym i Unii Europejskiej do przyjętej definicji konkurencyjności, można zauważyć, że pozycja Polski jest tym bardziej konkurencyjna, im wyższą wartość produkcji wytworzy. Analizując dane w tym zakresie, potwierdzono polepszenie pozycji konkurencyjnej polskiej branży meblarskiej w badanym przedziale czasowym. Rozważając konkurencyjność polskiej branży meblarskiej przez pryzmat wyników handlu zagranicznego, zauważono że podstawową cechą produkcji mebli w Polsce jest duży udział produkcji przeznaczonej na eksport. Potencjał produkcyjny branży lokuje Polskę na wysokiej pozycji zarówno wśród producentów, jak i eksporterów, odpowiednio na siódmym i czwartym miejscu globalnie i trzecim w Unii Europejskiej.

Należy jednak zwrócić uwagę na to, że na wynik ten składa się też sprzedaż mebli wyprodukowanych w Polsce pod znakiem firmowym przedsiębiorstw zlecających produkcję. Niewykorzystana pozostaje zatem siła własnych marek, której poprawa mogłaby jeszcze bardziej zintensyfikować proeksportowy charakter branży. Należy wskazać, że pomimo rosnącej produktywności polskich firm wytwarzających meble, produkcja mebli w Polsce jest tradycyjnie pracochłonna i charakteryzuje się jedną z najniższych w Unii Europejskiej wydajnością pracy. Szukając przesłanek decydujących o relatywnie dużej zdolności konkurencyjnej polskiego przemysłu meblarskiego, wskazano przede wszystkim na niskie koszty pracy. Wydaje się, że do poprawy zdolności konkurencyjnej niezbędne są zmiany organizacyjne i technologiczne, które przełożą się na zwiększenie wydajności pracy w polskiej branży meblarskiej. Biorąc pod uwagę wysoką w porównaniu z pozostałymi gałęziami przetwórstwa przemysłowego pozycję polskiej branży meblarskiej na rynku międzynarodowym, należy podkreślić, że sektor ten zasługuje na intensywną promocję i wsparcie ze strony administracji publicznej.

\section{Literatura}

Bieńkowski W. i in. (2008), Czynniki i miary międzynarodowej konkurencyjności gospodarek w kontekście globalizacji-wstępne wyniki badań, Prace i materiały, nr 284, Instytut Gospodarki Światowej SGH, Warszawa.

Bossak J.W. (2013), Konkurencja i wspótpraca międzynarodowa, Difin, Warszawa. Centre for Industrial Studies (2014), The EU Furniture Market Situation and a Possible Furniture Products Initiative. Final Report, Brussels, November. 
Daszkiewicz N. (red) (2008.), Konkurencyjność. Poziom makro, mezo i mikro, Wydawnictwo Naukowe PWN, Warszawa.

Eurostat, Manufacture of furniture statistics - NACE Rev. 2, sbs_na_ind_r2 (data dostępu: 21 lipca 2015).

Flejterski S. (1984), Istota i mierzenie konkurencyjności międzynarodowej, Gospodarka Planowa, nr 9.

Gorynia M. (2009), Teoretyczne aspekty konkurencyjności [w:] Gorynia M., Łaźniewska E. (red.), Kompendium wiedzy o konkurencyjności, Wydawnictwo Naukowe PWN, Warszawa.

Gorynia M., Jankowska B. (2008), Klastry a międzynarodowa konkurencyjność i internacjonalizacja przedsiębiorstwa, Difin sp. z o.o., Warszawa.

Grupa Doradców Biznesowych BAA, Sektor meblarski w czasie i przestrzeni. Ocena standingu adaptacyjności sektora, www.bcc.org.pl/blz/pliki/raporty/ MEBLE_XI_2011.pdf.

GUS, Dane wojewódzkie, http://stat.gov.pl/statystyka-regionalna/ (data dostępu: 20 lipca 2015).

GUS (2007), Polska Klasyfikacja Działalności (2007), http://stat.gov.pl/Klasyfikacje/doc/pkd_07/pkd_07.htm (data dostępu: 20 lipca 2015).

GUS (2012), Rocznik statystyczny przemystu 2012, Zakład Wydawnictw Statystycznych, Warszawa.

GUS (2013), Rocznik statystyczny przemystu 2013, Zakład Wydawnictw Statystycznych, Warszawa.

GUS (2014), Rocznik statystyczny przemystu 2014, Zakład Wydawnictw Statystycznych, Warszawa.

Jankowska B. (2009), Konkurencyjność w ujęciu mezoekonomicznym [w:] M. Gorynia, E. Łaźniewska (red.), Kompendium wiedzy o konkurencyjności, Wydawnictwo Naukowe PWN, Warszawa.

Krugman P. (1994), Competitiveness: A Dangerous Obsession, Foreign Affairs March/April 1994 Issue.

Market Quest (2014), Rynek produkcji mebli w Polsce. Ocena konkurencyjności i perspektywy rozwoju branży, Copyright BSI sp. z o. o., Warszawa.

Misala J. (2005), Wymiana międzynarodowa i gospodarka światowa. Teoria i mechanizmy funkcjonowania, Szkoła Główna Handlowa w Warszawie, Warszawa.

Person Ch., Salenbier G. (1983), Trade Employment and Adjustment Essays in International Economics, Montreal.

Porter M.E. (1990), The Competitive Advantage of Nations, Harvard Business Review 68, No. 2.

Radło M.J. (2008), Miary konkurencyjności gospodarki. Uwagi na temat definicji, czynników i miar, Instytut Gospodarki Światowej SGH, Warszawa, http:// radlo.org/mkg.pdf.

Sztando A. (1999), Konkurencyjność przedsiębiorstw przemysłowych $w$ układzie województw w latach 1992-1996 - wstępna próba analizy, Prace Naukowe Akademii Ekonomicznej we Wrocławiu nr 807, Wrocław. 
United Nations Industrial Development Organisation (2013), The Industrial Competitiveness of Nations. Looking back, forging ahead, Vienn.

Wysokińska Z. (2002), Konkurencyjność w międzynarodowym i globalnym handlu towarami technologicznie intensywnymi (high-tech), Studia Europejskie 1/2002. Wziątek-Kubiak A. (2003), Konkurencyjność polskiego przemysłu, Dom Wydawniczy Bellona, Warszawa.

\section{Streszczenie}

Zagadnienie międzynarodowej konkurencyjności ma kluczowe znaczenie we współczesnej gospodarce światowej. Przy tym coraz większą popularność zyskuje przekonanie, że o konkurencyjności gospodarki narodowej decydują jej poszczególne sektory, które tę konkurencyjność kształtują. Celem artykułu jest określenie pozycji konkurencyjnej polskiego przemysłu meblarskiego za pomocą analizy statystycznej. Przeprowadzone badania wskazują, że Polska jest jednym z najszybciej rozwijających się pod względem poziomu produkcji rynków meblarskich w Unii Europejskiej. Potencjał produkcyjny branży sytuuje Polskę na wysokiej pozycji zarówno wśród producentów, jak i eksporterów. Ponadto zagregowane dane potwierdzają poprawę pozycji konkurencyjnej polskiej branży meblarskiej w badanym okresie.

Słowa kluczowe: przemysł meblarski, pozycja konkurencyjna, ekonomia branży

\section{Summary}

The furniture industry in Poland and its international competitive position

The issue of international competitiveness is crucial in today's global economy. Moreover the belief that the competitiveness of the national economy is created by various sectors is gaining popularity. The aim of the article is to indicate the competitive position of the Polish furniture industry using statistical analysis. The study indicates that Poland is one of the fastest growing furniture markets in the European Union in terms of production levels. The production potential of the industry places Poland on a high position among manufacturers and exporters. In addition, aggregated data confirm the improvement in the competitive position of the Polish furniture industry in the analysed period.

Keywords: furniture industry, competitive position, industrial economics

JEL: F14 